\title{
THE INFLUENCE OF PHYSICAL ENVIRONMENT ON EMOTION, SATISFACTION AND BEHAVIORAL INTENTION OF PATIENTS TREATED
}

\section{Alvin Hendellyn}

Graduate School of Hospital Management, Universitas Pelita Harapan, Indonesia. alvin.hendellyn@gmail,com

Innocentius Bernarto Graduate School of Hospital Management, Universitas Pelita Harapan, Indonesia. bernarto227@gmail.com

\begin{abstract}
The purpose of this study is to analyze and examine the influence of physical environment on emotion, satisfaction and behavioral intention of patients treated in Siloam Hospital Lippo Village. This study was conducted using a quantitative approach and an explanatory method. This study involved 100 inpatients treated in Siloam Hospital Lippo Village. The data was collected by using questionnaire processed with PLS-SEM using SmartPLS software. The results showed that physical environment has a direct positive influence on emotion and satisfaction, but does not have a direct influence on behavioral intention of patients treated in Siloam Hospital Lippo Village. This study suggests Siloam Hospital Lippo Village to keep paying attention on the physical environment of the hospital as it can affect the patient's emotions, satisfaction and behavioral intention.
\end{abstract}

Keywords: Keywords:Physical Environment, Emotion, Patient Satisfaction, Behavioral Intention

\section{INTRODUCTION}

Indonesia is one of the largest countries in terms of its population. In 2017, Indonesia is the third most-populated country in the world (264 million) after India and USA respectively. The amount of population in Indonesia affects the quality of health service. Further, in 2017, according to Statistics Indonesia, there were $28.62 \%$ of Indonesians complained about their health problem. The amount of people seeking for medical attention is followed by the number of hospital growth whose number keeps increasing every year. This also increases the satisfaction level of the health service. This competitive market condition indicates that the primary key to gain profit is by giving a high-quality service that can create a positive customer satisfaction (Han and Ryu, 2007).

Along with the rapid development of service marketing today, service excellence has become a very important thing. Various business fields engaged in providing services strive to always improve their ability to serve and meet the customer needs. This has become such an obligatory for companies to offer good and high-quality service. A good service quality can create repeat purchases or recurrent service usage, customer 
loyalty and competitive product differentiation. In addition, it is also able to increase word-of-mouth (WOM) - a positive statement from customers on the services provided. The word-of-mouth is very important in service because it can increase the profitability of a company (Rangkuti, 2009). Economic development, investment and regional autonomy have led to the growth of a number of private and public hospitals in Indonesia, but many patients still made complaints.

This is evidenced by the continuous increase in the number of people seeking treatment abroad. The reason is because they are driven by technological excellence, medical capabilities and hospitality services to patients. Siloam Hospital Lippo Village is one of private hospitals with an international standard. It is one of the health service centres that many patients visit when they need medical care. Due to a high demand of medical services, staffs at the Siloam Hospital must perform well to be able to provide good services so as to produce satisfaction for their patients. During the implementation of the provision of medical services, Siloam Hospital certainly faces many issues related to the element of service quality and satisfaction given to the patients. This can be seen based on the patients' satisfaction data obtained from surveys provided by the hospital to the inpatients before they return home.

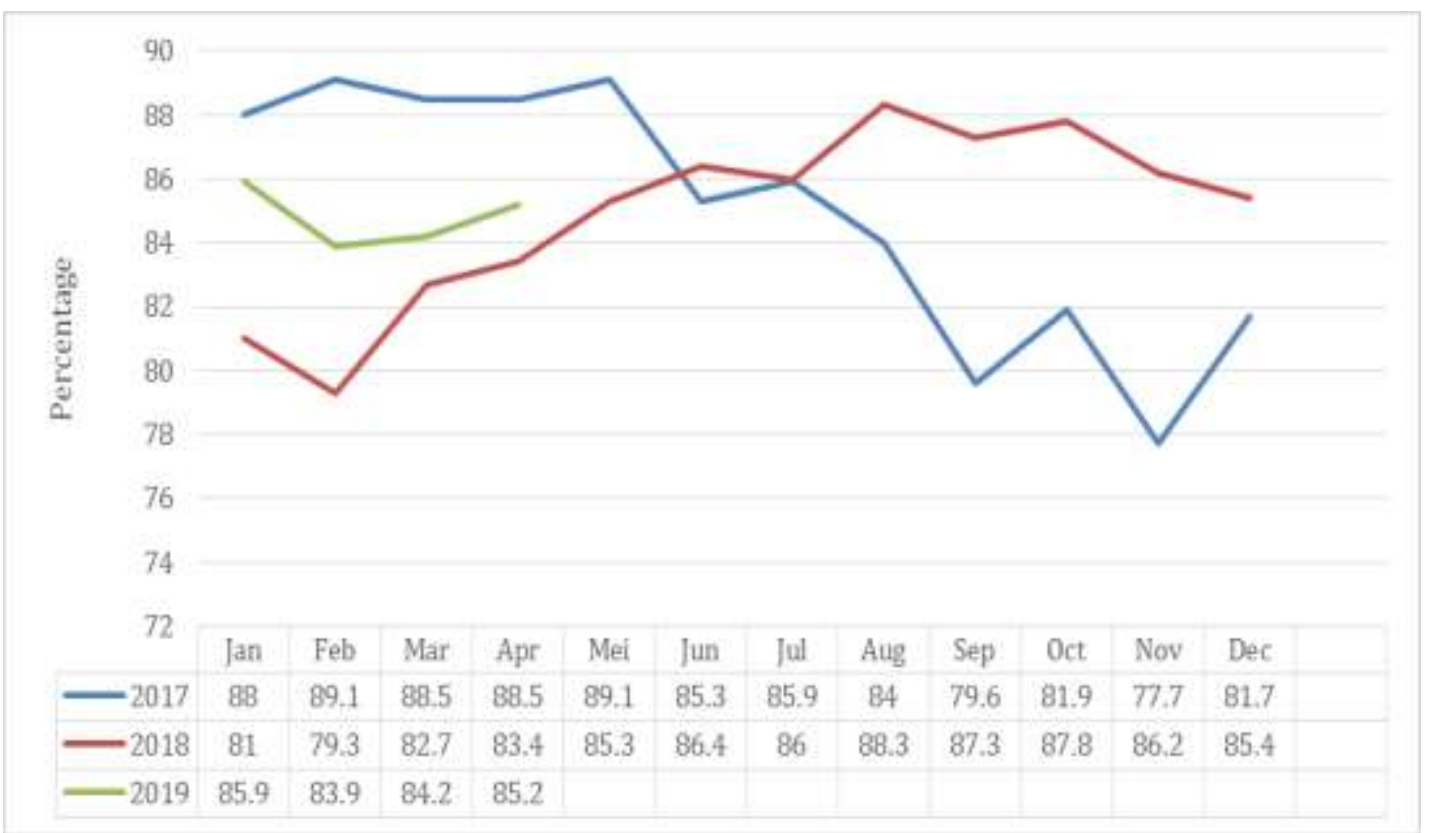

Figure 1. Siloam Hospital Lippo Village Patients' Satisfaction from January 2017-April 2019. Source: HR of Siloam Hospital Lippo Village.

The data is the percentage of the Siloam Hospital Lippo Village patients' satisfaction in January 2017to April 2019. Overall, the patients' satisfaction is quite high and ranges from $80-85 \%$. However, there is a decrease, especially in the middle to the end of 2017 . Although there is an increase in 2018 , however, towards the end of 2018, it is decreasing. There is also a decline in February 2019. In 2017, two significant decreases happen in September and November. In addition, based on the results of a brief interview with the Human Resources (HR) of Siloam Hospital Lippo Village, of the approximately 10.000 patients who come every month, it is expected that $100 \%$ of them will return. However, in fact, only $75 \%-80 \%$ of them return. Further, in terms of the patients' behavioral intention, such as whether the patients recommend the hospital to others or whether 
they spread positive word-of-mouth, it still cannot be proven empirically as there has been no previous researches focusing on the issue. Therefore, based on these data, there is an empirical gap between the expectation and reality which happens due to several factors. This study aims to analyze and examine the influence of physical environment on emotion, satisfaction and behavioral intention of patients treated in Siloam Hospital Lippo Village. This study uses a research model from a prior research by Ali and Amin (2014) in a hotel setting to a hospital setting. Factors influencing the behavioral intention towards the patients' satisfaction, the relationship between the patients' emotion and the physical environment to behavioral intention and the patients' satisfaction at the Siloam Hospital Lippo Village will be elaborated.

\section{LITERATURE REVIEW AND HYPOTESHIS}

\section{Behavioral Intention}

According to Kotler and Armstrong (2014), behavioral intention refers to "a condition where customers have intentions or attitudes loyal to brands, products and companies and willingly share their superiority with others". While according to Schiffman, Hansen and Kanuk. (2008), behavioral intention determines the possibility of consumers to take certain actions in the future. Dharmmesta and Handoko (2008) defined it as a behavior or attitude of consumers who have the desire to use the services continuously. Saha and Theingi (2009) considered it as the possibility of customers to perform certain behaviors such as positive word-of-mouth about a service provider to others, having the intention of repurchasing and being loyal. Based on the definitions mentioned, it can be concluded that behavioral intention is an indication of how people / customers are willing to try and how much effort they plan to mobilize in an effort to perform the behavior.

The five main dimensions of behavioral intention, according to what was stated by Zeithaml, Berry and Parasuraman (1996), are loyalty to the company, willingness to pay more, propensity to switch, external and responses to problems. These five dimensions contain two effects: positive and negative. The positive effect includes loyalty to the company and the desire to pay more. Meanwhile, the negative effect includes the propensity to switch and the external response to problems. The last effect, the internal response to problem, is considered non-significant (Parasuraman, Zeithaml and Berry, 2009). The dimensions of intention behavior shared by Bloemer, de Ruyter and Wetzels (1999) are re-purchase intention, word-of-mouth communication, price sensitivity and complaining behavior.

\section{Hypothesis Development}

\section{Relationship between Physical Environment and Emotions}

Customer's emotions, or in this case patient's emotions, are the customer's initial assessment of a product or service offered. Emotions can influence the customer's decision whether to buy/use or not the product/service offered. At the present, many hospitals are concerned with the physical environment as a tangible factor in the medical services offered to patients. Various physical environments include lighting, noise, vibration and etc. They can affect a patient's emotions where if it is positive, it will have a positive impact on the healing process of patients. There is a study explaining that the physical environment could affect the patients cognitively and emotionally (Burns and Niesner, 2006; Kim, Kim, and Lennon, 2009). 
$\mathbf{H}_{\mathbf{1}}$ : $\quad$ Physical environment has a positive influence on patients' emotion in Siloam Hospital Lippo Village

\section{Relationship between Physical Environment, Patients' Satisfaction and Behavioral Intention}

Every customer looking for health services will have certain expectations for the services they will get. Therefore, as a service provider, a hospital must provide the best service. The well-organized and pleasant physical environment for patients can accelerate the healing process. It is based on a research by Huisman and Kort (2013) regarding the healing environment which involves the physical environment of the treatment room with the healing of patients. If the patients recover faster, the patients' satisfaction will also increase. The physical environment also affects the behavioral intention. A study of environmental psychology observed and studied the relationship between a good physical environment and the patients' positive behavioral intention (Jang, Liu, and Namkung, 2011; Martin, Rouel, Jouany, Doreau, and Chilliard, 2008).; Wakefield and Blodgett, 1996; Mehrabian and Russell, 1974). A positive or negative behavioral intention will be influenced by a good or poor physical environment.

$\mathbf{H}_{2}$ : Physical environment has a positive influence on patients' satisfaction

H3: Physical environment has a positive influence on behavioral intention

\section{Relationship between Patients' Emotions, Satisfaction and Behavioral Intention}

Emotions are closely related with patients' satisfaction. Patients who feel happy when they are getting a good service will show a positive attitude based on their positive emotions. On the contrary, those who are not satisfied with the service received will show disappointment or anger reflected by negative emotions. According to Oliver (1997), assessing a service received would depend on the emotional status of a person and any changes in the patient's emotional status would affect their level of satisfaction. The same thing also happens to the emotional connection to the behavioral intention. It is obvious that currently, the role of emotions in the service sector is the topic that has received the most attention from researchers/experts. Emotions are one of the predictors of customers' behavioral intention (Andreu et al., 2006; Westbrook and Oliver, 1991). When customers get a positive experience and have positive emotions, they will show a level of satisfaction where they will use the service or service provider in the future, and spread positive word-of-mouth to others (Jang and Namkung, 2009).

H4: Emotions has a positive influence on patients' satisfaction

H5: Emotions has a positive influence on behavioral intention

\section{Relationship between Patients Satisfaction and Behavioral Intention}

The positive influence between customer satisfaction and behavioral intention has been very well known and can be accepted by many parties. Behavioral intention, as explained earlier, refers to a condition where the customer has an intensity and loyalty to an agency or product offered. In this case, at the hospital context, the patients' behavioral intention will be greatly influenced by their satisfaction as a high level of satisfaction will shape loyalty which is very influential on the behavioral intention (Zamani and Tarokh, 2016).

H6: Patients satisfaction has a positive influence on behavioral intention 


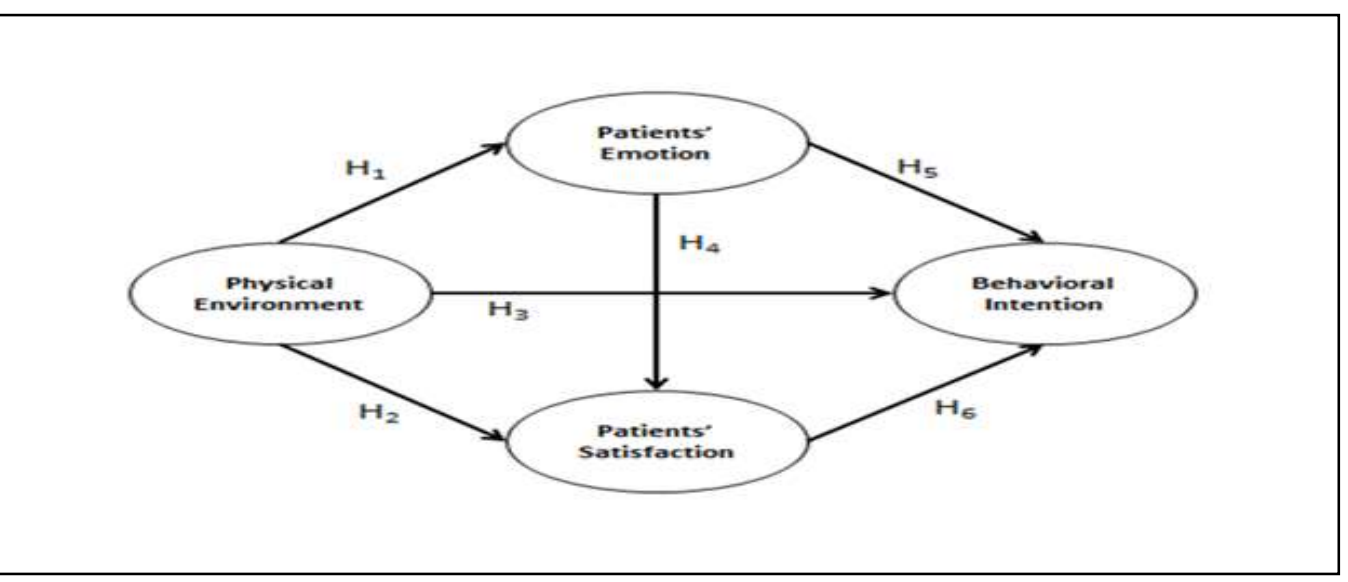

Figure 2. Research Model

\section{METHODS}

This study aims to analyze and examine the effect of the physical environment on patients' emotions, patients' satisfaction and behavioral intention of inpatients in at the Siloam Hospital Lippo Village. The independent variable was the physical environment, while the patients' emotions, patients' satisfaction were mediating variables and behavioral intention was the dependent variable. The target population was all inpatients at the Siloam Hospital Lippo Village, involving 100 patients. The sampling technique used was convenience sampling.

A questionnaire was distributed to all inpatients at the Siloam Hospital Lippo Village. The data collected was analyzed by using PLS-SEM statistical analysis through the SmartPLS program. There were 16 statements in the questionnaire explaining the physical environment, patients' emotions, patients' satisfaction and behavioral intention variables. The measurement of questionnaire items used a 5-point Likert scale where $1=$ strongly disagree, $2=$ disagree, $3=$ neutral, $4=$ agree, and $5=$ strongly agree. The data obtained were examined for validity and reliability in the measurement model (outer model). An instrument was considered valid if the average variance extraction (AVE) value $>0.5$, cross loading $>0.7$, and the discriminant analysis met the Fornel-Larcker criteria. A reliability test was done by considering the composite reliability value which must be > 0.7 (Ghozali and Latan, 2015; Hair et al., 2014). In addition, a structural model (inner model) was examined to see the multicollinearity and hypotheses testing.

\section{RESEARCH RESULTS}

The respondents' profile showed that the number of female respondents $(=52 \%)$ was higher than male respondents $(=48 \%)$. Their educational background ranged from high school $(=34 \%)$, diploma $(=10 \%)$ to a bachelor degree $(=42 \%)$ and the other $(=14 \%)$. Their aged ranged from less than 21 years old $(=5 \%), 22-27$ years old $(=13 \%), 28-32$ years old $(=9 \%), 33-37$ years old $(=16 \%), 38-42$ years old $(=17 \%), 43-47$ years old $(=7 \%)$ and more than 47 years old $(=33 \%)$. The length of treatment ranged from less than 3 days $(=46 \%), 3-7$ days $(=44 \%)$, more than 7 days $(=10 \%)$. 


\section{Outer Model}

The outer model was carried out to assess the validity and reliability of the model proposed. This research was conducted by considering convergent validity, discriminant validity, and composite reliability (Ghozali \& Latan, 2015). Based on Ghozali and Latan (2015), the rule of thumb for convergent validity is loading factor $>0.7$ and average variance extracted $(A V E)>0.5$. The AVE value must be greater than the latent variable correlation and if cross loading was examined, its value should be $>0.7$. The value of outer loading between 0.4 to 0.7 can still be used as long as the AVE value is greater than 0.5 (Hair et al., 2014). The discriminant validity test used the Fornell-Larcker criteria where the square root value of AVE must be greater than the value of the relationship between constructs (Hair et al, 2014). Table 1. show that all of AVE value are valid where they meet the minimum criteria of $>0.5$ (rule of thumb).

\section{Structure Equation Model}

The analysis result is shown in Figure 2, we found that all hypotheses are supported except hypotheses $\mathrm{H} 1$ that peer communication have not direct effect on online impulse buying, while peer communication have indirect effect on online impulse buying. Usage intensity has direct and indirect effect on online impulse buying. This can be seen from $t$ statistic $\mathrm{H}_{2}-\mathrm{H} 7$ bigger than $\mathrm{t}$ table which is 1.988 .

Table 1. Measurement Model Evaluation

\begin{tabular}{|c|c|c|c|}
\hline & Constructs and Items & Outer Loading & p-value \\
\hline \multicolumn{4}{|c|}{ Physical Environment $(\mathrm{AVE}=0.666, \mathrm{CR}=0.888)$} \\
\hline PE 1 & Comfortable room temperature & 0.701 & $0.000^{*}$ \\
\hline PE2 & Clean room & 0.794 & $0.000^{*}$ \\
\hline PE3 & Adequte room and bathroom facilities & 0.881 & $0.000 *$ \\
\hline PE4 & Comfortable patient bed & 0.875 & $0.000^{*}$ \\
\hline \multicolumn{4}{|c|}{ Emotions (AVE $=0.843, C R=0.955)$} \\
\hline E1 & After undergoing treatment, I feel Elated & 0.886 & $0.000^{*}$ \\
\hline E2 & After undergoing treatment, I feel Enthusiastic & 0.955 & $0.000^{*}$ \\
\hline E3 & After undergoing treatment, I feel Impressed & 0.924 & $0.000 *$ \\
\hline E4 & After undergoing treatment, I feel Proud & 0.905 & $0.000^{*}$ \\
\hline \multicolumn{4}{|c|}{ Patient Satisfaction $(\mathrm{AVE}=0.698, \mathrm{CR}=0.901)$} \\
\hline PS1 & $\begin{array}{l}\text { I am satisfied with my decision choosing this } \\
\text { Hospital }\end{array}$ & 0.896 & $0.000 *$ \\
\hline PS2 & I received the treatment as expected & 0.920 & $0.000 *$ \\
\hline PS3 & $\begin{array}{l}\text { I was explained clearly about my condition and } \\
\text { the treatment plan }\end{array}$ & 0.809 & $0.000^{*}$ \\
\hline PS4 & $\begin{array}{l}\text { I am satisfied with the quality of foods and } \\
\text { beverages in this hospital }\end{array}$ & 0.698 & $0.000^{*}$ \\
\hline \multicolumn{4}{|c|}{ Behavioral Intention (AVE $=0.765, C R=0.929)$} \\
\hline $\mathrm{B} \mid 1$ & $\begin{array}{l}\text { I intend to comeback to this hospital for medical } \\
\text { treatment }\end{array}$ & 0.784 & $0.000 *$ \\
\hline $\mathrm{Bl} 2$ & $\begin{array}{l}\text { I will consider this hospital as my first choice to } \\
\text { get medical treatment }\end{array}$ & 0.909 & $0.000^{*}$ \\
\hline $\mathrm{Bl} 3$ & I will recommend this Hospital to other people & 0.904 & $0.000 *$ \\
\hline $\mathrm{Bl} 4$ & $\begin{array}{l}\text { I will spread positive word-of-mouth about this } \\
\text { hospital }\end{array}$ & 0.896 & $0.000 *$ \\
\hline
\end{tabular}

Description: AVE= average variance extracted; CR: composite reliability; * significant (two-tailed test, $p<0.05$ )

270 Management and Economics Journal (MEC-J)

Vol 3 (3) December 2019 
The next table presents the results of the discriminant validity test showing the AVE square root value and the value of the relationship between constructs. Also, based on the Table 1., all composite reliability has also met the minimum requirement of rule of thumb ( $>0.7)$. Therefore, said it can be concluded that all variables are considered reliable. The reliability test was carried out by measuring the composite reliability value. A construct is considered to have a good reliability if the value of composite reliability is above 0.7 (Ghozali and Latan, 2015). In table 2, all the result fulfil the Fornell-Larcker criteria, which is that the test results of AVE square root values are greater than the value of the relationship between constructs.

Table 2. Discriminant Validity Test

\begin{tabular}{|c|c|c|c|c|}
\hline Variables & Behavioral intention & Emotions & Patients satisfaction & Physical environment \\
\hline Behavioral intention & 0.875 & & & \\
\hline Emotions & 0.794 & 0.918 & & \\
\hline Patients satisfaction & 0.829 & 0.806 & 0.836 & \\
\hline Physical environment & 0.522 & 0.604 & 0.639 & 0.816 \\
\hline
\end{tabular}

\section{Structural Model}

In structural model, testing was carried out to measure the multicollinearity and RSquare $\left(R^{2}\right)$ measurements. The measurement of multicollinearity aims to see the relationship between the independent constructs existed whether there is a tendency for collinearity or not. It was done by looking at the value of the Variance Inflation Factor (VIF) which aims to find out whether there is a collusion in the independent construct or not. According to Hair et al. (2014), the VIF value must be less than 5. If the VIF value is more than 5 , the research model experiences multicollinearity problems.

Table 3. Nilai Variance Inflation Factor (VIF)

\begin{tabular}{|c|c|c|c|c|}
\hline Variables & $\begin{array}{l}\text { Behavioral } \\
\text { Intention }\end{array}$ & Emotions & $\begin{array}{c}\text { Patients } \\
\text { Satisfaction }\end{array}$ & $\begin{array}{c}\text { Physical } \\
\text { Environment }\end{array}$ \\
\hline \multicolumn{5}{|l|}{ Behavioral Intention } \\
\hline Emotions & 2.968 & & 1.547 & \\
\hline Patients satisfaction & 3.189 & & & \\
\hline Physical Environment & 1.757 & 1.000 & 1.574 & \\
\hline
\end{tabular}

Based on Table 3. above, it can be seen that all independent variables have VIF values of less than 5 . This means that the patients' behavioral intention, emotions, satisfaction and physical environment do not have multicollinearity. In addition to the VIF values, testing the structural models can be done by evaluating the $R^{2}$ (R-square) value for each endogenous latent variable as the predictive power of the structural model. R-square explains to what extent the independent construct explains the dependent construct. 
Table 4. R-Square

\begin{tabular}{ll}
\hline Table $4 \cdot \mathrm{R}$ & Square \\
\hline Table $4 \cdot \mathrm{R}$ & Square \\
Table $4 \cdot \mathrm{R}$ & Square \\
Table $4 . \mathrm{R}$ & Square \\
\hline
\end{tabular}

The table above shows the results of R-square calculation, which is equal to $0.727(72.7 \%)$ for behavioral intention, 0.358 (35.8\%) for patients' emotion and 0.680 (68\%) for patients' satisfaction.

\section{Hypotheses Testing Result}

Ghozali and Latan (2015) stated that $\mathrm{t}$-value could be an indication whether a hypothesis was supported or not. A hypothesis could be considered significant if the $t$-value $>1.65$ with a significance level of $5 \%$. Based on table 5 , all hypotheses are supported, except $\mathrm{H}_{3}$ which has a t-value of -0.070 .

Table 5. Hypothesis Testing Result

\begin{tabular}{|c|c|c|c|}
\hline Hypothesis & $\begin{array}{l}\text { Standardized } \\
\text { Coefficient }\end{array}$ & t-statistic & Decision \\
\hline $\begin{array}{l}\mathrm{H}_{1}: \text { Physical Environment has a Positive Influence } \\
\text { on Patients Emotions }\end{array}$ & 0.604 & 10.727 & Supported \\
\hline $\begin{array}{l}\mathrm{H}_{2}: \text { Physical Environement has a Positive Influence } \\
\text { on Patients Satisfaction }\end{array}$ & 0.240 & 2.871 & Supported \\
\hline $\begin{array}{l}\mathrm{H}_{3} \text { : Physical Environment has a Positive Influence } \\
\text { on Behavioral Intention }\end{array}$ & -0.070 & -0.807 & $\begin{array}{c}\text { Not } \\
\text { Supported }\end{array}$ \\
\hline $\begin{array}{l}\mathrm{H}_{4} \text { : Patients Emotions has a Positive Influence on } \\
\text { Patients Satisfaction }\end{array}$ & 0.661 & 9.408 & Supported \\
\hline $\begin{array}{l}\mathrm{H}_{5} \text { : Patients Emotions has a Positive Influence on } \\
\text { Behavioral Intention }\end{array}$ & 0.377 & 3.709 & Supported \\
\hline $\begin{array}{l}\mathrm{H}_{6} \text { : Patients Satisfaction has a Positive Influence on } \\
\text { Behavioral Intention }\end{array}$ & 0.570 & $5 \cdot 547$ & Supported \\
\hline
\end{tabular}

\section{DISCUSSION}

This study aims to understand and examine the influence of the physical environment on the patients' emotion, satisfaction and behavioral intention, also the influence of the patients' emotions on patients' satisfaction, and behavioral intention and the influence of patients' satisfaction on behavioral intention. The first hypothesis, stating that the physical environment has a positive influence on the patients' emotions at the Siloam Hospital Lippo Village, is empirically supported. This indicated that the better the physical environment of a hospital, the positive the patients' emotions. It was in accordance with previous study by Ali and Amin (2014); Burns and Niesner (2006); Kim, Kim, and Lennon (2009). The physical environment itself had an important role in 
supporting the healing process of inpatients. The comfort factor including room temperature, noise, patients' beds, patients' room and bathroom facilities would support the healing process. In this study, the most significant physical environment indicators were a comfortable bed, followed by adequate room and bathroom facilities, overall cleanliness of the treatment room and room temperature.

The second hypothesis, stating that the physical environment has a positive influence on the patients' satisfaction at the Siloam Hospital Lippo Village, is empirically supported. The physical environment had a significant value on the patients' satisfaction. It indicated that the better the physical environment, the higher the patients' satisfaction. The results were supported by Ali and Amin (2014); Huisman and Kort (2013). In this study, it was found that the patients' satisfaction was greatly influenced by the care received which was in accordance with their expectations. Siloam Hospital Lippo Village was known as an international hospital. Therefore, the patients admitted to this hospital would have a high expectation for the treatment received. In addition to the treatment, the room to be occupied was also one of the concerns. Therefore, a conducive room would result to a positive influence on the patients' satisfaction.

The third hypothesis, stating that the physical environment has a positive influence on behavioral intention, is not empirically supported. It is because it has a t-value of $<1.65$, which showed that although Siloam Hospital Lippo Village had a good physical environment, it did not guarantee that the patients would result to a positive behavioral intention. This result was not supported by a study by Ali and Amin (2014).

The fourth hypothesis, stating that the patients' emotion has a positive influence on the patients' satisfaction, is empirically supported. The results show that the more positive the patients' emotions, the higher the patients' satisfaction(Ali and Amin, 2014; Andreu et al., 2006; Westbrook and Oliver, 1991). The positive emotions could be given by meeting their expectations, especially if the hospital could exceed the patients' expectations. The most emotions experienced after being treated at the Siloam Hospital were feeling enthusiastic, followed by impressed, proud and finally happy.

The fifth hypothesis, stating that the patient's emotions have a positive influence on behavioral intention, is empirically supported. It has a significant value of 3.709. Previous research by Ali and Amin (2014) and Jang and Namkung (2009) supported that the more positive the emotions, the more positive the behavioral intention as well. The behavioral intention referred to in this study was that the patients would return to Siloam Hospital Lippo Village, recommend to others, spread positive words, and Siloam Hospital Lippo Village would be the patients' first-choice hospital.

The sixth hypothesis, stating that the patients' satisfaction has a positive influence on behavioral intention, is empirically supported. Study by Ali and Amin (2014); Zamani and Tarokh (2016) also supports this result. Based on the results, this hypothesis has a significant and quite high number of 5.547. The patients' satisfaction that was strongly influenced by the patient's emotions would affect the patient's behavioral intention. Therefore, the more satisfied the patients, the more positive the patients' behavioral intention. 


\section{CONCLUSION}

As mentioned earlier, this study aims to analyze and examine the influence of physical environment on patients' emotions, patients' satisfaction and behavioral intention of inpatients treated in Siloam Hospital Lippo Village. This study concludes that the physical environment had a positive influence on the patients' emotions. Therefore, the better the physical environment, the more positive the patients' emotion.

Second, the physical environment had a positive influence on the patients' satisfaction. Therefore, the better the physical environment, the higher the patients' satisfaction toward Siloam Hospital Lippo Village.

Third, the physical environment did not have a positive influence on the behavioral intention. Therefore, although there was a good physical environment, it did not affect the behavioral intention of the inpatients of Siloam Hospital Lippo Village.

Fourth, the patients' emotion was proven to have a positive influence on the patients' satisfaction. Therefore, the more positive the patients' emotions, the higher the patients' satisfaction of Siloam Hospital Lippo Village.

Fifth, the patients' emotion was found to have a positive influence on the behavioral intention. Thus, the more positive the patient's emotions, the more positive the behavioral intentions of the inpatients of Siloam Hospital Lippo Village.

Last, the patients' satisfaction had shown to have a positive influence on the behavioral intention. Therefore, the higher patient satisfaction, the more positive the behavioral intention of the inpatients of Siloam Hospital Lippo Village.

\section{Limitations and Suggestions}

The limitations of this study are that the inpatients involved were only from a single ward, the Bethsaida ward. Therefore, the influence of the physical environment of other wards on the patients' emotion, satisfaction and behavioral intention were not included in the study this. Future researches are suggested to a different ward or to combine several wards. In addition, this study might have a bias as there were different nurses taking care of the inpatients. Thus, the nurses' response to the patients who were the respondents of this study might have affected the patients' emotion, and simultaneously affecting the results of this study. Therefore, future researchers should consider to choose subjects with a more homogenous condition so the bias can be avoided or minimized.

\section{REFERENCES}

Ali, F., \& Amin, M. (2014). The influence of physical environment on emotions, customer satisfaction and behavioural intentions in Chinese resort hotel industry. J. Global Business Advancement, 7(3), 249-266.

Andreu, L., Kozak, M., Avci, N., \& Cifter, N. (2006). Market Segmentation by Motivations to Travel. Journal of Travel \& Tourism Marketing, 19(1), 1-14.

Arikunto, S. (2012). Prosedur penelitian suatu pendekatan praktek. Jakarta: Rineka Cipta

274 Management and Economics Journal (MEC-J)

Vol 3 (3) December 2019 
Bloemer, J., de Ruyter, K. \& Wetzels, M. (1999). Linking Perceived Service Quality and Service Loyalty: A Multi-dimensional Perspective. Journal of Marketing, 33(11-12), 10821106.

Burns, D. \& Neisner, L. (2006). Customer satisfaction in a retail setting: The contribution of emotion. International Journal of Retail \& Distribution Management, 34(1), 4966.

Dharmmesta, B.S., \& Handoko, T.H. (2008). Manajemen pemasaran : Analisis perilaku konsumen. Yogyakarta.

Ghozali, I. \& Hengky, L. (2015). Concept, technique, application using SmartPLS 3.0 for emphirical study. Semarang: BP UNDIP.

Hair, J.F., Hult, G.T.M., Ringle, C.M., \& Sarstedt, M. (2014). A primer on partial least squares structural equation modeling (PLS-SEM). Califronia, USA: SAGE Publications, Inc.

Han, H., \& Ryu, K. (2007). Moderating role of personal characteristics in forming restaurant customers' behavioral intentions: an upscale restaurant setting. Journal of Hospitality \& Leisure Marketing, 15(4), 25-54.

Huisman, K.J.M., \& Kort, P.M., (2013). Strategic Capacity Investment Under uncertainty, Discussion Paper 2013-003, Tilburg University, Center for Economic Research.

Jang, S. \& Namkung, Y., 2009. Perceived quality, emotions, and behavioral intentions: Application of an extended Mehrabian-Russell model to restaurants. Journal of Business Research, 62(4), $451-460$.

Jang, S.S., Liu, Y., \& Namkung, Y. (2011). Effects of authentic atmospherics in ethnic restaurants: investigating Chinese restaurants. International Journal of Contemporary Hospitality Management, 23(5), 662-680.

Kim, J., Kim, M., \& Lennon, S. (2009). Effects of web site atmospherics on consumer responses: music and product presentation. Direct Marketing: An International Journal, 3(1), 4-19.

Kotler, P., \& Armstrong, G. (2014). Principle of marketing. New Jersey : Pearson Prentice Hall.

Martin, C., Rouel, J., Jouany, J. P., Doreau, M., \& Chilliard, Y. (2008). Methane output and diet digestibility in response to feeding dairy cows crude linseed, extruded linseed, or linseed oil. J. Anim. Sci., 86 (10), 2642-50.

Mehrabian, A., \& Russell, J. A. (1974). An approach to environmental psychology. Cambridge, MA, US: The MIT Press.

Oliver, R. L. (1997). Satisfaction: A behavioral perspective on the consumer. New York: McGraw- Hill.

Parasuraman, A., Zeithaml, V. A., \& Berry, L. L. (2009). Servqual. Journal of Retailing, 64(1), $12-40$. 
Rangkuti, F. (2009). Creative Promotion Strategy and Integrated Marketing Communication Case Analysis. Jakarta: PT. Gramedia Pustaka Utama.

Saha,G.C, \& Theingi. (2009), Service quality, satisfaction, and behavioural intentions. Managing Service Quality: An International Journal, 19(3), 350-372.

Westbrook, R., \& Oliver, R. (1991). The dimensionality of consumption emotion patterns and consumer satisfaction. Journal of Consumer Research. 18(1), 84-91.

Zamani, E., \& Tarokh, M.J. (2016). Analysis of customer relationship management in hospitals and present an efficient model for CRM implementation in hospitals. Bulletin de la Société Royale des Sciences de Liège, 85, 1448-1456.

Zeithaml, V. A., Berry, L.L., \& Parasuraman, A. (1996). The Behavioral consequences of servcie quality. Journal of Marketing, 60(2), 31-46. 